\title{
PENGARUH PEMBERIAN SARI KECAMBAH KACANG HIJAU TERHADAP KADAR MALONDIALDEHID PADA IKAN LELE DUMBO (Clarias gariepinus) YANG TERINFEKSI BAKTERI Aeromonas hydrophila
}

\section{EFFECT OF MUNG BEAN SPROUTS ESSENCES AGAINST MALONDIALDEHYDE LEVELS IN AFRICAN CATFISH (Clarias gariepinus) THAT WAS INFECTED BY BACTERIA Aeromonas hydrophila}

\author{
Widy Ayunanti, Hari Suprapto dan Boedi Setya Rahardja \\ Fakultas Perikanan dan Kelautan Universitas Airlangga \\ Kampus C Mulyorejo - Surabaya, 60115 Telp. 031-5911451
}

\begin{abstract}
African catfish (Clarias gariepinus) is a type of freshwater fish consumption with elongated body and smooth skin. Bacterial disease that often strikes African catfish and can cause death as well as a cause of primary infection is A.hydrophila. Bacterial infection may be one cause of the synthesis of lipid peroxidation which is an indication of the emergence of free radicals. And the end result of lipid peroxidation is malondialdehyde.

Sprouts are the new little plants grow from seeds planted beans. Green bean seed germination will enrich vitamins including vitamin $\mathrm{E}$, green beans or $\alpha$-tocopherol. Vitamin $\mathrm{E}$ in maintaining the stability of the plasma membrane and protects the cell structure against damage caused by free radicals is by blocking the reaction initiation and propagation of lipid peroxidation reactions interrupt.

Data analyze of this research was used Varian Analyze (ANAVA) and to found the lowest level was used Duncan Test. The average yield of malondialdehyde levels in the negative control treatment is $0.0386 \mathrm{ng} / 100 \mathrm{mg}$ mass, positive control ( $1 \mathrm{ml}$ Aeromonas hydrophila $105 \mathrm{cfu}$ per 5 liter) is $0.0962 \mathrm{ng} /$ $100 \mathrm{mg}$ mass, sprout extract treatment $(0,1 \mathrm{ml}$ per fish) is $0.05 \mathrm{ng} / 100 \mathrm{mg}$ mass, germination and pollen treatment Aeromonas hydrophila is $0.0626 \mathrm{ng} / 100 \mathrm{mg}$ mass. From these results indicate that the highest levels found in the positive control treatment while the lowest levels found in the negative control. These results also suggest that decreased levels of malondialdehyde using pollen germination is very significantly different with $\mathrm{P}<0,01$.
\end{abstract}

Keywords : Mung bean sprouts essences, Malondialdehyde, The African catfish, Bacteria Aeromonas hydrophila

\begin{abstract}
Pendahuluan
Budidaya ikan lele merupakan salah satu budidaya air tawar yang sudah dikembangkan sejak dahulu hingga sekarang. Namun salah satu permasalahan pada budidaya ikan lele dumbo adalah masalah penyakit yang disebabkan oleh beberapa pathogen salah satunya adalah bakteri. Bakteri yang paling berbahaya yang dapat menyebabkan kematian pada ikan lele dumbo ini adalah Aeromonas hydrophila. Bakteri ini ganas dan menyebabkan kematian lebih dari $60 \%$ dalam waktu 7 hari (Kamiso dan Triyanto, 1994). Bakteri ini menyerang berbagai jenis ikan air tawar seperti Lele Dumbo (Clarias gariepinus), Ikan mas (Cyprinus carpio), Gurami (Osphronemus gouramy) dan Udang Galah (Macrobracium rusenbergii). Bakteri Aeromonas hydrophila dapat menimbulkan wabah penyakit dengan tingkat kematian tinggi (80-100\%) dalam waktu 1-2 minggu (Sari, 2009). Pada tahun 2006,
\end{abstract}

Komisi Kesehatan Ikan dan Lingkungan Nasional telah menetapkan jenis penyakit merah yang disebabkan Aeromonas hydrophila sebagai salah satu penyakit ikan utama di Indonesia (Taukhid, 2010). Adanya infeksi bakteri dapat menjadi salah satu penyebab terjadinya pembentukan peroksidasi lipid yang merupakan indikasi munculnya radikal bebas. Karena hasil akhir dari peroksidasi lipid adalah malondialdehid. Kandungan malondialdehid yang tinggi dalam tubuh dapat menyebabkan radikal bebas (Arkhaesi, 2008).

Kecambah memiliki kandungan serat kasar dan protein serta vitamin yang baik digunakan atau dikonsumsikan pada ikan lele dumbo. Perkecambahan biji kacang hijau akan memperkaya kandungan vitamin kacang hijau diantaranya vitamin $\mathrm{E}$ atau a-tokoferol.

Vitamin E dalam memelihara stabilitas membran plasma dan melindungi struktur sel terhadap kerusakan yang disebabkan oleh 
radikal bebas adalah dengan membloking reaksi inisiasi dan menginterupsi reaksi propagasi peroksidasi lipid. Sehingga dengan adanya vitamin $\mathrm{E}$ dari kecambah tersebut mampu menghambat reaksi radikal bebas pada ikan lele dumbo. Atas dasar pemikiran tersebut maka diadakan penelitian ini untuk memberikan informasi tentang manfaat dari kecambah serta pengaruhnya terhadap kadar malondialdehid.

Tujuan Penelitian ini yaitu untuk mengetahui pengaruh pemberian sari kecambah kacang hijau terhadap penurunan kadar malondialdehid dalam tubuh ikan lele dumbo (Clarias gariepinus) yang terserang Aeromonas hydrophila dan untuk mengetahui konsentrasi terendah malondialdehid pada penelitian.

\section{Materi dan Metode}

Bahan yang digunakan pada penelitian ini adalah Ikan lele dumbo (Clarias gariepinus) yang diambil dari pasar ikan "Patua" dengan berat 13 - 15 gram dan panjang $11-13 \mathrm{~cm}$. Bahan yang digunakan selanjutnya yaitu kecambah kacang hijau yang didapat dari pasar Mojoarum, Surabaya. Bakteri Aeromonas hydrophila $10^{5} \mathrm{cfu} / \mathrm{ml}$ yang diambil dari laboratorium mikrobiologi Fakultas Kedokteran Hewan Universitas Airlangga, Surabaya. Bahan-bahan lain yang digunakan diantaranya Plastik, Botol Film, TBA, Pelet, HCl, Buffer Phospate dan TCA.

Metode yang digunakan yaitu metode eksperimen dengan mengukur daya antioksidan sari kecambah kacang hijau dalam menurunkan kadar malondialdehid pada ikan lele dumbo yang terinfeksi bakteri Aeromonas hydrophila.

Uji Tantang Ikan Lele Dumbo terhadap Bakteri Aeromonas hydrophila

Uji tantang pada penelitian ini adalah dengan meneteskan $1 \mathrm{ml}$ bakteri Aeromonas hydrophila dengan kepadatan $10^{5} \mathrm{cfu} / \mathrm{ml}$ pada ikan lele dumbo dan menunggu selama 24 jam. Dosis tersebut dipilih karena berdasarkan penelitian yang telah dilakukan Kamiso $d k k$ (1994) bahwa antara dosis rendaman bakteri Aeromonas hydrophila $10^{4}-10^{7} \mathrm{cfu} / \mathrm{ml}$ yang memiliki rata-rata waktu kematian yang optimal yaitu pada dosis $10^{5} \mathrm{cfu} / \mathrm{ml}$. Kemudian memberikan sari kecambah kacang hijau sebanyak $0,1 \mathrm{ml}$ pada ikan lele dumbo secara oral setiap hari dan mengamati perubahannya selama 7 hari.

Ada empat perlakuan pada penelitian ini. Perlakuan pertama (K-) sebagai kontrol yaitu tanpa diberi bakteri Aeromonas hydrophila dan sari kecambah kacang hijau, perlakuan kedua $(\mathrm{K}+)$ yaitu Ikan lele dumbo dengan penambahan sari kecambah kacang hijau sebanyak 0,1 ml melalui oral (sonde), perlakuan ketiga (SKC) yaitu Ikan lele dumbo dengan penambahan Aeromonas hydrophila $10^{5}$ $\mathrm{cfu} / \mathrm{ml}$ secara rendaman sebanyak $\pm 1 \mathrm{ml}$ per 5 liter air selama 24 jam, perlakuan keempat (BKC) yaitu Ikan lele dumbo dengan penambahan sari kecambah kacang hijau sebanyak $0,1 \mathrm{ml}$ melalui oral (sonde) dan bakteri Aeromonas hydrophila $10^{5} \mathrm{cfu} / \mathrm{ml}$ secara rendaman $\pm 1 \mathrm{ml}$ per 5 liter air selama 24 jam. Variabel bebas pada penelitian ini yaitu konsentrasi bakteri dan konsentrasi sari kecambah kacang hijau.

Cara mengukur kadar malondialdehid (MDA) Pengukuran kadar malondialdehid otak ikan lele diawali dengan menimbang otak ikan lele sebanyak $100 \mathrm{mg}$ kemudian sampel otak tersebut di homogenasi dengan larutan Buffer phosphate sebanyak $2 \mathrm{cc}$. Kemudian ambil 200 $\mu l$ sampel yang sudah dihomogenasi, tambahkan dengan 0,5 cc aquades lalu tambahkan $200 \mu \mathrm{l}$ HCL 0,1 N, kemudian tambahkan $250 \mu \mathrm{l}$ Trichlorid acetic acid $40 \%$ serta tambahkan $250 \mu \mathrm{l}$ Thiobarbiturict acid. Setelah itu, panaskan pada suhu $100^{\circ} \mathrm{C}$ selama 20 menit. Kemudian di sentrifus dengan kecepatan $3000 \mathrm{rpm}$ dan mengambil supernatannya dengan ditambahkan $3 \mathrm{cc} \mathrm{H}_{2} \mathrm{O}$. Setelah itu baru di baca pada spektrofotometer dengan panjang gelombang $\lambda 532 \mathrm{~nm}$.

\section{Hasil dan Pembahasan}

Sebelum mengetahui hasil penelitian yang dilakukan untuk uji malondialdehid maka perlu dilakukan pemeliharaan ikan lele dumbo terlebih dahulu yang di infeksikan dengan bakteri Aeromonas hydrophila. Untuk memastikan apakah bakteri tersebut merupakan bakteri Aeromonas hydrophila maka perlu dilakukan uji biokimia. Berdasarkan hasil uji biokimia, bakteri A. hydrophila memiliki karakteristik biokimia yaitu bersifat motil, positif $\mathrm{H}_{2} \mathrm{~S}$, positif sitrate, positif indole dan menghasilkan gas. Setelah uji biokimia, maka ikan lele dumbo yang telah terinfeksi tersebut akan dipelihara Dari pengamatan secara makroskopis terhadap ikan lele selama 7 hari masa penelitian didapatkan hasil untuk perlakuan kontrol negatif menunjukkan gejala klinis yaitu tidak terdapat nodul/ luka di insang dan sirip serta warna permukaan tubuh normal. Kemudian untuk perlakuan kontrol positif menunjukkan gejala klinis yaitu terdapat banyak nodul dan luka di insang dan sirip serta warna permukaan tubuh pucat. Untuk perlakuan pemberian sari kecambah menunjukkan gejala 
klinis yaitu tidak terdapat nodul/ luka di insang dan sirip, serta warna permukaan tubuh agak pucat. Sedangkan untuk perlakuan bakteri $A$. hydrophila dan sari kecambah menunjukkan gejala klinis yaitu terdapat sedikit nodul dan luka di insang dan sirip serta warna permukaan tubuh pucat.

Setelah masa pemeliharaan selama 7 hari, kemudian baru dilakukan uji malondialdehid secara laboratorium. Perlakuan yang berbeda menunjukkan hasil yang berbeda pula. Hasil kadar malondialdehid dapat dilihat pada tabel 1 .

Tabel 1. Perbedaan rata-rata hasil kadar MDA

\begin{tabular}{|l|c|}
\hline \multicolumn{1}{|c|}{ Perlakuan } & Rata-rata \pm SD \\
\hline $\begin{array}{l}\text { K- (kontrol } \\
\text { negatif) } \\
\text { K+ (kontrol } \\
\text { positif) }\end{array}$ & $0,037260^{\mathbf{c}} \pm 0,0048650$ \\
$\begin{array}{l}\text { SKC (sari } \\
\text { kecambah) }\end{array}$ & $0,061060^{\mathbf{c}} \pm 0,0074772$ \\
$\begin{array}{l}\text { BKC (sari } \\
\text { kecambah+ } \\
\text { bakteri) }\end{array}$ & $0,088520^{\mathbf{b}} \pm 0,0141643$ \\
\hline
\end{tabular}

Keterangan : Superscript yang berbeda pada kolom yang sama menunjukkan adanya perbedaan yang sangat nyata antar perlakuan $(\mathrm{P}$ $<0,01)$.

Uji lanjutan yang telah dilakukan menunjukkan bahwa hasil kadar malondialdehid terendah yaitu 0,0386 pada perlakuan kontrol negatif atau normal. Sedangkan untuk kadar malondialdehid tertinggi yaitu 0,0962 pada perlakuan kontrol positif. Hasil ini dapat ditunjukkan melalui gambar 1.
Hasil malondialdehid otak ikan lele menunjukkan bahwa untuk perlakuan kontrol negatif memiliki rata-rata kadar malondialdehid terendah, sedangkan pada perlakuan bakteri memiliki rata-rata kadar malondialdehid tertinggi. Sedangkan untuk dua perlakuan yang lain yaitu sari kecambah (SKC) dan sari kecambah dengan bakteri Aeromonas hydrophila (BKC) memiliki rata-rata kadar malondialdehid diatas rata-rata kadar malondialdehid kontrol negatif dan dibawah rata-rata kadar malondialdehid kontrol positif. Hal ini menunjukkan bahwa sari kecambah memiliki pengaruh untuk menurunkan kadar malondialdehid pada ikan lele yang terserang Aeromonas hydrophila.

Hasil malondialdehid melalui uji lanjutan Duncan menunjukkan bahwa hasil untuk sari kecambah yaitu berbeda sangat nyata dengan $\mathrm{P}<0,01$.

Hasil yang baik ialah menunjukkan bahwa kadar malondialdehid harus rendah, semakin rendah kadar malondialdehidnya maka akan mencegah bahaya radikal bebas tersebut. Karena malondialdehid adalah enzim yang aktif ketika tubuh terserang oleh penyakit atau bahaya lain yang menyebabkan radikal bebas.

Pada perlakuan pertama yaitu kontrol negatif didapatkan hasil yang terendah dapat dilihat pada grafik 1, hal ini dapat dikarenakan ikan tidak mengalami tingkat stress yang cukup tinggi akibat tanpa pemberian bakteri dan sari kecambah sehingga hasil kadar malondialdehidnya juga tidak terlalu tinggi. Hasil yang tertinggi yaitu pada perlakuan kontrol positif dapat dilihat pada grafik 1 diatas, hal ini dikarenakan bakteri Aeromonas hydrophila yang menginfeksi ikan lele dapat menyebabkan ikan menjadi stres akibat gangguan fisiologi serta gangguan pertahanan

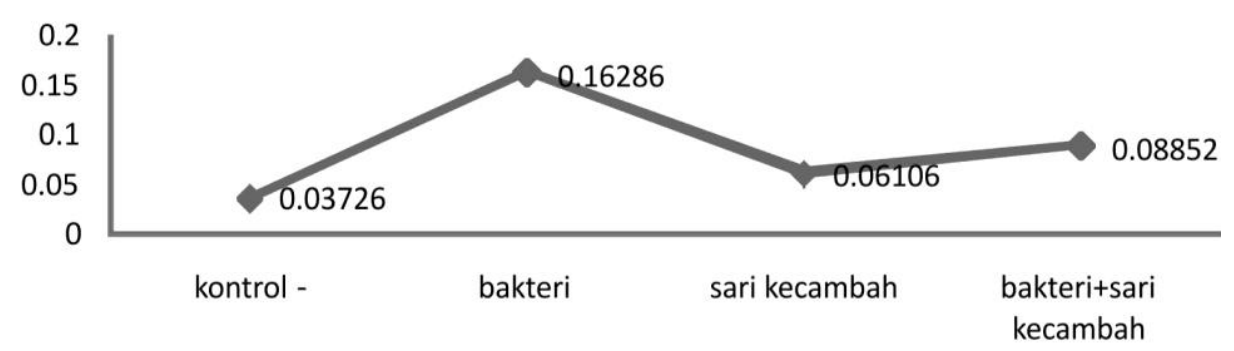

— Rata-rata hasil MDA

Gambar 1. Rata-rata hasil MDA setiap perlakuan 
tubuh. Oleh sebab itu malondialdehid yang dihasilkan pun meningkat.

Pada perlakuan ketiga yaitu pemberian sari kecambah, didapatkan nilai kadar malondialdehid terendah kedua dapat dilihat pada gambar 1, hal ini dapat disebabkan ketika proses pemberian sari kecambah pada ikan dilakukan dengan memasukkannya kedalam mulut ikan lele (sonde) sehingga ikan mengalami stres.

Pada perlakuan keempat yaitu pemberian bakteri Aeromonas hydrophila dan sari kecambah. Nilai kadar malondialdehidnya terendah ketiga, hal ini menunjukkan bahwa dengan pemberian sari kecambah dapat menurunkan kadar malondialdehid pada ikan lele yang terserang Aeromonas hydrophila tersebut.

Specific Oksigen Reaktif (SOR) terus menerus dibentuk dalam jumlah besar di dalam sel melalui jalur metabolik tubuh yang merupakan proses biologis normal karena berbagai rangsangan, misalnya radiasi, tekanan parsial oksigen $\left(\mathrm{pO}_{2}\right)$ tinggi, paparan zat-zat kimia tertentu, infeksi maupun inflamasi. Peningkatan SOR pada infeksi bakteri mempunyai potensi untuk menimbulkan kerusakan membran eritrosit. Eritrosit sangat rentan terhadap senyawa oksidan, dan sebagai akibat dari peristiwa peroksidasi lipid pada eritrosit adalah terjadinya lisis atau yang biasa dikenal dengan hemolisis. Terdapat dua mekanisme utama penghancuran eritrosit pada hemolisis, yaitu penghancuran berlebihan oleh sistem RE (hemolisis ekstravaskuler) atau eritrosit dihancurkan langsung dalam sirkulasi pada suatu proses (hemolisis intravaskuler). Mekanisme yang mendominasi tergantung pada patologi yang terlibat. Strategi yang digunakan anti-oksidan dalam meredam oksidan adalah strategi dua tahap, yaitu mencegah terhimpunnya senyawa-senyawa oksidan secara berlebihan dan mencegah reaksi rantai berlanjut. (Arkhaesi, 2008)

\section{Kesimpulan}

Dari hasil penelitian ini didapatkan kesimpulan yaitu hasil penelitian menunjukkan bahwa sari kecambah kacang hijau mampu menurunkan kadar malondialdehid ikan lele dumbo yang terserang Aeromonas hydrophila, untuk hasil kadar malondialdehid yang terendah hingga tertinggi secara berurutan yaitu terdapat pada perlakuan kontrol negatif yaitu 0,037260 dan hasil tertinggi pada perlakuan pemberian bakteri Aeromonas hydrophila $10^{5} \mathrm{cfu} / \mathrm{ml}$ yaitu 0,162860 .

\section{Daftar Pustaka}

Arkhaesi, N. 2008. Kadar Malondialdehyde (MDA) Serum Sebagai Indikator Prognosis Keluaran Pada Sepsis Neonatorum. Jurnal Penelitian Program Pascasarjana Magister Ilmu Biomedik Dan Program Pendidikan Dokter Spesialis-I Ilmu Kesehatan Anak Universitas Diponegoro, Semarang. Hal 10-12.

Austin, B. dan D.A. Austin. 1999. Bacterial Fish Pathogens : Disease of Farmed and Wild Fish (Third Edition). Praxis Publishing Ltd, Chichester, UK. Hal 19, 65, 205-206.

Sari, N. 2009. Pencegahan Dan Pengobatan Penyakit MAS (Motile Aeromonas Septicemia) Infeksi Bakteri Aeromonas hydrophila Pada Budidaya Ikan Air Tawar. Program Studi Biologi, Fakultas Matematika dan Ilmu Pengetahuan Alam, Institut Teknologi Sepuluh Nopember, Surabaya.

Taukhid. 2010. Hydrovac, Vaksin Bakteri Lawan Aeromonas. Majalah Trobos, 01 desember 2010 